\title{
ANALYSIS OF THE KINESIOLOGY OF SKATE SKIING AND ROLLER SKIING
}

\author{
Jiří Suchý, Bronislav Kračmar \\ Charles University in Prague, Prague, Czech Republic
}

\begin{abstract}
Jiří Suchý. PhD in Kinanthropology. Assistant at the Department of Didactics of Sport, Faculty of Physical Education and Sport, Charles
\end{abstract} University in Prague. Research interests - endurance sports, sport training.

\begin{abstract}
The peak of human locomotive ontogenesis is unsupported bipedal walking. We can assume that the patterns for locomotion in sport correspond to the patterns for walking. In this study the coordination of motion in six selected key muscle groups and one control group was observed during the use of cross-country skis with ski-poles on snow (free form, skating), and compared with the coordination using roller skis with poles on asphalt. The comparison was carried out skating up a slight slope. Intraindividual analysis of these forms of locomotion was based on surface electromyography (EMG) synchronized with digital video recorded in vivo on site. The data acquired were evaluated by calculating the area under the EMG curve recorded for each muscle under observation. The probability values acquired in this way roughly show the activation and work of the monitored muscle. An ordering of local maximums within a given step cycle was established in order to judge the coordination of motion.

The measured data confirmed the phenomenon of triple extension in the lower limbs as well as the phenomenon of pelvic stabilisation in the frontal plane in the single-support position. This stabilisation is ensured by the musculus gluteus medius, which was the only muscle measured to show a different ordering of local EMG curve maximums (timing) when comparing the whole cycle of skiing locomotion on asphalt and on snow. The peaks of activity for this muscle were localised outside the activity peaks of the musculus latissimus dorsi, which is considered the deciding muscle for locomotion realised through the shoulder girdle, but which also performs a stabilising function. Thus both muscles alternate in ensuring stability.
\end{abstract}

The results of the pilot study described demonstrate sufficient kinesiological correspondence between locomotion on skis and on roller skis with poles to confirm the suitability of regular use of roller skis as a specific training instrument for skiing.

Keywords: human locomotion, electromyography, skating on cross-country skis and on roller skis.

\section{INTRODUCTION}

I $n$ the course of the postural and locomotive ontogenesis of man, there is a functional maturing of the locomotive system in cranial and caudal development. In locomotion, the shoulder girdle is initially engaged, followed by the pelvic girdle. The combination of the functional maturing of the pelvic girdle and the acral part of the lower limb - the leg - facilitates standing upright and bipedal walking. The hand develops in preparati- on for its future grasping function. The shoulder girdle does not lose its locomotive function, but, as Vojta demonstrates (Vojta, Peters, 1995), that function merely becomes secondary to the primary functions of manipulation and grasping (Véle, 2006).

The forms of locomotion in civilised man are primarily reduced to walking and standing upright, and infrequently running. Walking is a locomotive 
activity that is directly facilitated solely by the pelvic girdle (its relation to the point of support), with a complementary balancing motion of the upper limbs. We find the shoulder girdle directly engaged in locomotion in selected sporting activities - climbing an artificial wall, paddling a canoe, the use of poles in cross-country skiing (skating and the classic technique), Nordic walking, and in swimming, in the front crawl and the backstroke (Kračmar, 2002).

To determine the postural muscles, Janda et al. (1996) sought the typical hominid posture or movement. He formulated bipedal walking for the pelvic girdle. The locomotive model of the pelvic girdle does not correspond to the locomotive model of man's closest biological relatives, the primates and the apes, where we do not find the perfect capacity to stand upright for bipedal locomotion (Vacková, 2004; Vančata, 1996). Fully upright bipedal walking is therefore specific to the human species.

Véle (2006) lists manipulation and grasping as the typical functions of the shoulder girdle. We tried to find an equivalent for the locomotive function of the shoulder girdle (i.e. for a function that is atypical in ordinary life). We designated the progress of motion during Vojta's reflexive crawling as a typically human locomotive movement in the shoulder girdle (Kračmar, 2001; Vacková, 2004).

In terms of ontogeny, we find certain similarities and differences between walking and skating on cross-country skis. The main difference is the engagement of the muscle groups for the work of the upper limbs during skating on cross-country skis; it is as though the skier has returned to quadrupedality by creating a place of support for the upper limbs. We anticipate muscular coordination in the shoulder girdle, which has its equivalent in the ontogenetic forms of human locomotion (Vojta, Peters, 1995). However, we see the quadrupedal character of locomotion as having specific features resulting from the vertical posture of the body, inducing the function of the body's stability system. That stability system was not activated for the horizontal posture of the body in the early stages of hominid locomotive ontogenesis (Schmalhausen, 1968; Véle, 2006).

Gliding posture and push.

The gliding posture on skis naturally does not provide the sensation of postural stability. The stereotype of walking is reinforced daily, on firm surfaces, where the tarsus 'grasps', is supported

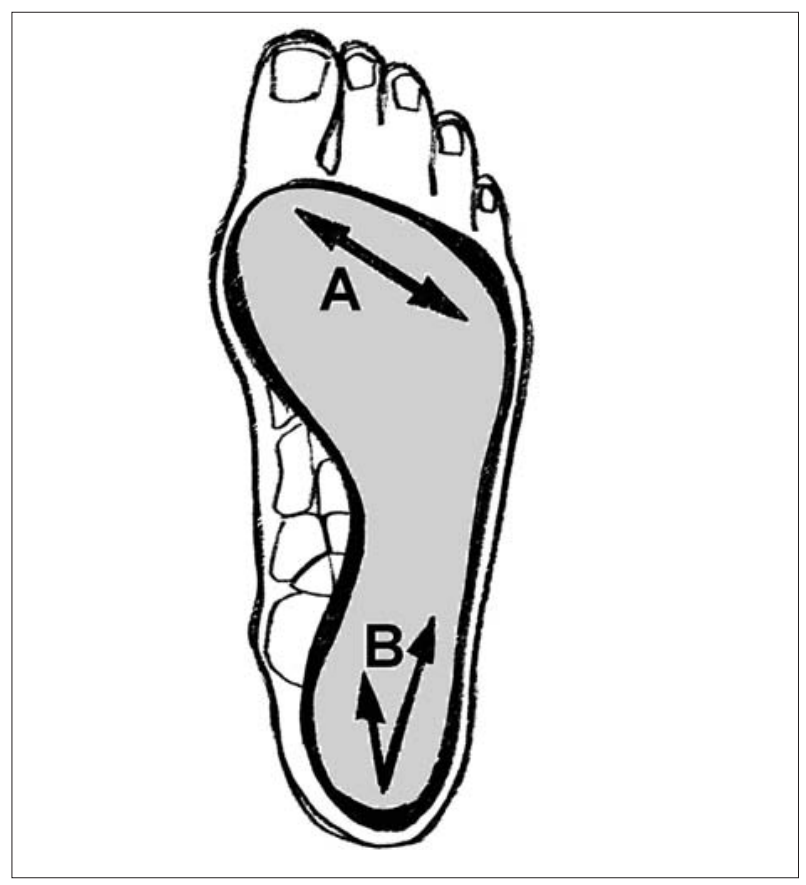

Figure 1. Trajectory of the median across the support base while standing on one leg (according to Kapandji)

by and deflects from a firm and stable place of support. In ordinary life, man avoids gliding. In gaining optimal postural stability while gliding on one ski, the forces acting on the skier (with an advanced technique) become balanced, and postural stability increases to the point that it resembles the sensation of standing at rest on a firm (i.e. non-slip) surface.

I. Vařeka (2004) demonstrated the localisation of the trajectory of the median across the support base when standing on one leg. He alternately applied a load to the front and rear parts of the foot, thereby simulating the dynamics of walking. He elaborated a static, three-point model of the foot according to A. J. Kapandji (1987) - Figure 1.

The trajectory of the median across the support base copies that three-point model. When the foot makes contact with a firm base, support begins at the heel, continues along the outer edge of the foot, there is then pronation, and in the course of the step the push moves forwards to the medial edge of the tarsus and finishes with the toes. That progress of support is substantiated by the structure of the foot. We find the most massive bone structure on the heel. The most massive bones in the toes are the medial metatarsi and the phalanges of the hallux. The push then proceeds from the sole of the foot at the heel, along its outer edge, and as it moves forward it shifts to the inner side of the foot, which corresponds to the progress of support and pushing when skating on crosscountry skis. Standing on one foot and the push 
from the inner side of the foot during skating on cross-country skis therefore have features that are defined in the ontogeny of postural stability. Maintaining posture on the sole of the foot and its inner edge also corresponds to the bipedal arrangement of the lower limbs in the frontal plane. In postural instability while standing, the base is extended, and the weight of the body is transferred to the inner edges of the feet. When novices skate on cross-country skis, we see that they cannot keep the skis flat while gliding, and proceed on the inner edges of the skis.

For reasons of stability, the most demanding technique for skating on cross-county skis, singlepoling skating, was chosen for monitoring. For each pole there is one push by one lower limb. The interval between two pushes with the right leg, i.e. one step with the left leg, one step with the right leg and two poles with the arms working in synchrony, was defined as one motion cycle.

The choice of single-poling skating for monitoring was not random. Training in skating on cross-county skis begins with single-poling skating (Gnad, Psotová, 2005). The present competitive form of that skating technique is used to an ever-greater extent.

\section{METHODS}

Skating on cross-country skis and skating on roller skis with poles were chosen for monitoring locomotion through the pelvic girdle. Electromyographic (EMG) measurement was carried out in the field; we do not have any reports of similar field monitoring in the Czech Republic or abroad.

The subject is a top league competitive crosscountry skier. He has trained and competed in cross-country skiing for 15 years, he is 29 years of age, with no medical complications. We worked on the assumption that the kinesiology of his locomotive motion on cross-country skis is in accordance with the principles of human motor ontogenesis. If that were not so, the long-term performance of that locomotive activity would have led to the stressing and pathology of the structures involved. That claim is supported by the fact that the subject has never suffered serious injury throughout his career in sport, despite the high volume and intensity of training (approximately 700-1 000 hours of training in his annual training cycle). A kinesiological analysis did not reveal any pathological changes that could have been caused by his sporting activities.
Measuring was conducted without any change to the sensitivity of the channels recording EMG potentials. There was a difference between both sets of measurements in the density of sampling during that recording, which resulted in a difference in the smoothness of the curves for both sets of measurements (details are available from the authors). Surface electromyography was carried out on six accessible muscles involved in engaging the pelvic girdle and lower limbs in locomotion (for reasons of space, the exact localisation is in a periodical available from the authors), and one muscle was monitored as the marker for evidence of engagement in the crossed locomotive pattern:

1. m. gluteus maximus $\mathrm{dx}$.

2. m. gluteus medius $d x$.

3. m. tibialis anterior $\mathrm{dx}$.

4. m. quadriceps femoris $\mathrm{dx}$, vastus medialis

5. $\mathrm{m}$. adductor longus $\mathrm{dx}$.

6. m. gastrocnemius dx., cap. medialis

7. m. latissimus dorsi sin.

M. latissimus dorsi, as the only contralateral muscle, was monitored for its possible engagement in the quadrupedal crossed locomotive pattern. It represents the muscle group on the rear side of the torso. It begins at the humerus ( $\sin )$, continuing through the processi spinosi and the $\mathrm{m}$. fasciae latae (dx.), m. gluteus maximus (dx.), m. biceps femoris (dx.) to the fibula.

The timing of the inception and decline of EMG potentials was monitored, which helped to create a kinesiological chart of motion, a kind of 'coordination map'.

A portable KAZE5 measuring instrument (developed at the Charles University in Prague, Faculty of Physical Education and Sport) was used, with seven channels for recording EMG potentials, and one working channel for synchronising the video recording. The weight of the instrument, with batteries and including a belt bag fastened around the waist of the research subject, was $1.4 \mathrm{~kg}$. Sensitivity regulation is $0.05-2 \mathrm{mV}$, the adjustable measurement duration was 5 seconds $-4 \mathrm{mi}$ nutes 50 seconds. Following the completion of a series of $1-7$ measurements, a record from the instrument's internal memory was transferred to a laptop, processed by the KAZE5 software and exported into the latest version of Microsoft Excel. There was also a synchronised video recording. In the analysis there was an attempt to achieve the highest level of regularity in the EMG potentials recorded. 
The research subject's equipment consisted of Rollerski Jeseník roller skis, Salomon SNS bindings and boots, Fischer skis, and Salomon Pilot bindings and boots. For both tests we used Swix poles with PCC handles and Velcro fasteners.

In evaluating the results, the emphasis was placed on the timing of the inception and decline of EMG potentials for the muscles monitored. Monitoring was intraindividual. Measurements were taken for the same sportsman at an interval of two months. Before the first session on roller skis on October 19, 2007, the research subject had had no significant specific training. Training for the winter season (running, cycling, weight training) included roller skiing, with a weekly training session of approximately 90 minutes. By the time of the session on skis on December 21, 2007, the subject had completed approximately 900 training kilometres on snow, focusing on the regeneration of his technique and developing special aerobic capacities.

Specific features of the locomotive activity monitored

The start and end of the cycle monitored, i.e. a double step, is defined as the moment at which the pushing foot (here the right foot) leaves the ground.

The muscles, which are only engaged laterally, work only once during each cycle $-\mathrm{m}$. gluteus medius $(\mathrm{dx})$. and $\mathrm{m}$. gastrocnemius $(\mathrm{dx})$ - positions 1 and 10 . The positions are shown in figures 4 and 4. M. gluteus maximus ( $\mathrm{dx})$. and $\mathrm{m}$. latissimus dorsi ( $\sin )$., $\mathrm{m}$. adductor longus (dx)., abd m. vastus medialis $(\mathrm{dx})$. are muscles that facilitate both steps by the lower limb, and have two significant peaks during the cycle monitored - positions 1 , 6 and 10.

\section{RESULTS}

Figure 2 shows the process during skating on snow; Figure 3 shows the timing of the muscles monitored. The different positions in Figure 2 are numbered $1-11$, and are also shown in Figure 3. Skating on roller skis is presented in the same way in Figures 4 and 5.

For the purposes of simplicity, one 'step' with the lower right limb is analysed, i.e. from the moment the right foot leaves the ground to the same moment in the following cycle, positions 1 and 11 . For reasons of the phasic shift in the activity of certain muscles, the related parts of the auxiliary steps are also depicted.
The nature of single-poling skating results in poling before the push by the lower limb. Poling is represented by the contralateral $\mathrm{m}$. latissimus dorsi ( $\sin )$ - positions 4 and 9 . It is part of the muscle group on the rear side of the torso.

The sequence for the activation of the muscles monitored is as follows: $\mathrm{m}$ latissimus dorsi (sin.) is activated before position 1 , followed by $\mathrm{m}$. gluteus maximus (dx.) just before position 1, almost simultaneously with $\mathrm{m}$. vastus medialis (dx.) - position 1. The wave of activation to complete the push continues to $\mathrm{m}$. gastrocnemius (dx.) - position 1 . We simultaneously observe a decline in the activity of $\mathrm{m}$. tibialis anterior (dx.) - positions 1 and 11, which allows the leg a position for tarsal flexion (i.e. the push). We find here then the phenomenon of the triple extension of the joints of the pushing (right) lower limb. That phenomenon is present

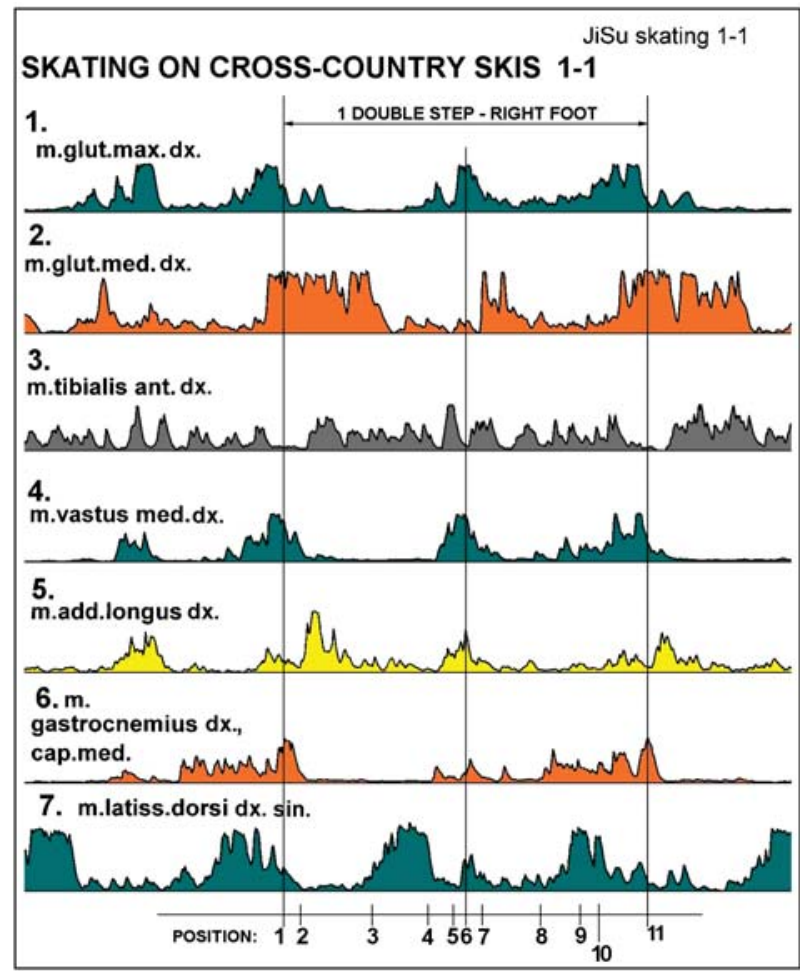

Figure 2. Process of skating on cross-country skis

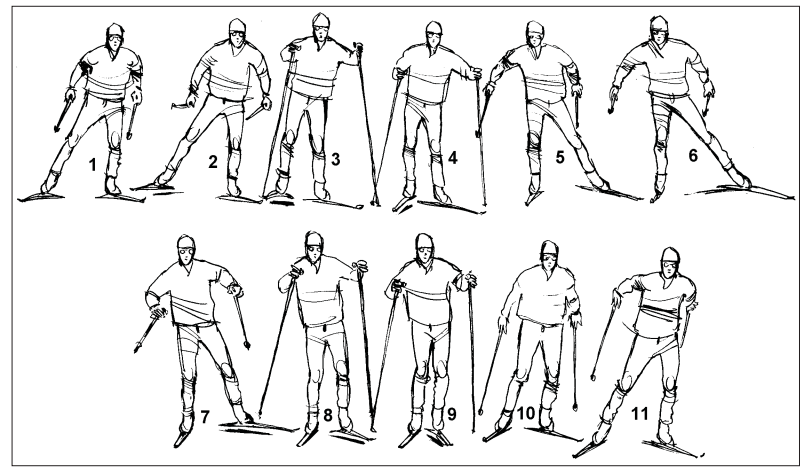

Figure 3. Timing of the monitored muscles (on cross-country skis) 


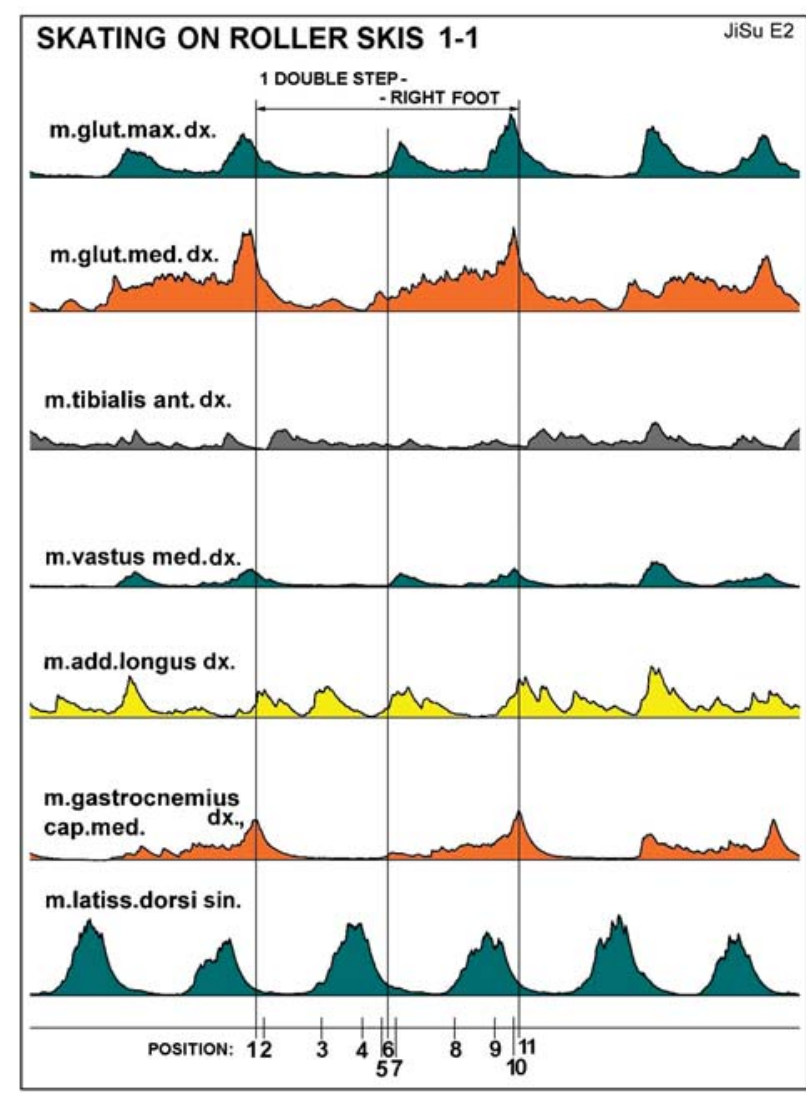

Figure 4. Process of skating on roller skis

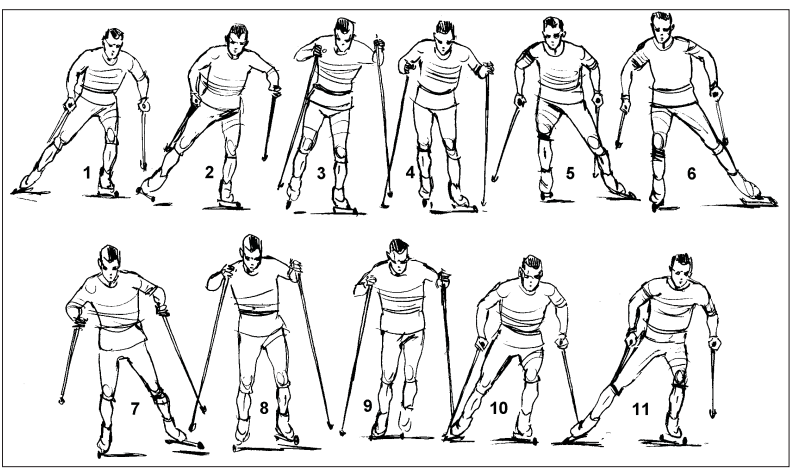

Figure 5. Timing of the monitored muscles (on roller skis)

in the locomotion of the majority of quadrupedal tetrapods (Romer, 1966; Shubin, Alberch, 1986; Young, 1981), and is phylogenetically conditioned. There is then the activation of $\mathrm{m}$. adductor longus (dx.) - position 2, which adducts the lower limb to the standing limb for effective gliding on one leg. M. adductor longus (dx.) is clearly activated while travelling on the other, i.e. the left, ski. It works almost symmetrically during travelling on each ski - positions $2,3,7,11$.

M. gluteus maximus (dx.) also displays a second significant peak - position 7 .

That shows the entire pelvis in retroversion during the completion of the push. The unequal distances between the peaks in the activation of that muscle (the position before $1,7,10$ ) during al- ternating extension in the pelvis on the side of the pushing and gliding leg illustrate the slight rotation of the pelvis around a vertical axis, always towards the gliding ski. A reversed shift on the other side can be expected for the contralateral $\mathrm{m}$. gluteus maximus sin, which was not measured.

The second peak for the activation of m. gluteus maximus (dx.) is not part of the triple extension - position 7. The simultaneous activation of the ipsilateral $\mathrm{m}$. tibialis anterior (dx.) corresponds to the position of the standing leg in the gliding posture, where the position of the knee and ankle joints (position 7) does not correspond to the phenomenon of triple extension. Here the muscle supports the retroversion of the pelvis during the push with the second lower limb (i.e. the requirement to move both hips forward at the completion of the push). A variable that was not monitored, and which could influence the function of $\mathrm{m}$. tibialis anterior (dx.), could be the use of different bindings during the measurements for roller skis and on snow. There is a slight difference in the way SNS and Pilot bindings influence the motion in the ankle joint in the sense of dorsal and tarsal flexion.

The contralateral $\mathrm{m}$. latissimus dorsi ( $\sin$.) also has a two-peak activation cycle - the positions before 1, 4 and 9, when its engagement in the muscle group facilitates poling during the push of each lower limb. In comparison with the activation of $\mathrm{m}$. gluteus maximus (dx.), the peaks for its activation are regular. That corresponds to the optimal direction for the vector for poling, with arms and poles moving forwards in the direction of travel. The different placing of the peak activation of $\mathrm{m}$. adductor longus (dx.) - positions 2, 7 and 11 - has a cause similar to that of m. gluteus maximus (dx.). It works following the push - positions 1 and 10, when it helps return the lower limb from abduction to adduction, and the second peak is when it works on the standing (gliding) lower limb to maintain the gliding posture on one leg - position 7 .

The activation of $\mathrm{m}$. gluteus medius (dx.) rises and peaks at the moment of the push. The push is depicted as the peak activation of $\mathrm{m}$. gluteus maximus (dx.) - the position before 1 and 10 .

A further comparison of the activation of the muscles monitored during skating on snow and skating on roller skis reveals that the timing of the inception and completion of the activation of the muscles monitored is identical in both types of sport. 


\section{DISCUSSION}

The validity of the results is derived from the nature of the research project - a case study. The shortcomings of this kind of research are ameliorated by the selection of the research subject, a competitive skier with a relatively stable advanced technique that has been assessed by experts over a five-year period.

A variable that was not monitored, and which could influence the function of $\mathrm{m}$. tibialis anterior (dx.), could be the use of different bindings during the measurements for roller skis and on snow. There is a slight difference in the way SNS and Pilot bindings influence the motion in the ankle joint in the sense of dorsal and tarsal flexion.

In one place - the activation of $\mathrm{m}$. gluteus medius (dx.) - the 'coordination maps' of both types of skating monitored diverge: positions 2 and 11 in Figure 3, and the position before 1 and 10 in Figure 5. Moreover, in skating on snow we find another activity peak - the position between 7 and 8 in Figure 3. On snow, the dominant activity peak is shifted further in time than when skating on roller skis. M. gluteus medius (dx.) maintains the stability of the pelvis in the frontal plane, so that the future pushing leg does not descend to the ground prematurely - the position before $1-3$. On snow, where the variability of the ground is somewhat greater than on asphalt, that control of the stability of the pelvis is evidently longer and more emphatic. The longer control of the position of the pelvis may correspond to the greater coordination of the motion of the sportsman following the completion of 900 kilometres of training on snow. M. gluteus medius (dx.) helps to control the more fluid placing of the ski on the snow in the direction of the future glide of the ski. In that way, the ski does not descend to the ground.

\section{CONCLUSION}

Field EMG monitoring has allowed the coordination of the human motion monitored to be objectified and specified in vivo. The outcome of that measuring is a 'coordination map', or a kinesiology of motion in the technique of an advanced cross-country skier. For skating on skis, the phenomenon of the triple extension of the pushing lower limb was described, and the stabilisation effect of $\mathrm{m}$. gluteus medius was discovered for the pelvic region. The timing described between the muscle group and the muscles of the pelvis and lower limb are an indicator for a description of an effective technique for skate skiing. They are simultaneously evidence of the nature of the work of the monitored part of the locomotive system in quadrupedal locomotion. Evidence of that is the timing of activation from $\mathrm{m}$. latissimus dorsi ( $\sin$.) to $\mathrm{m}$. gastrocnemius (dx.).

The sole difference in the coordination of motion between skating on snow and on roller skis was discovered in the timing of the engagement of m. gluteus medius. Only a different methodology in a subsequent measuring session, excluding the one variable not monitored, can determine the cause of that phenomenon. Either that is a specific aspect of both activities monitored, or the change is influenced by the completion of substantial training between the two sessions.

This research is supported by GAUK112/2006 and MSM0021620864.

\section{REFERENCES}

Gnad, T., Psotová, D. (2005). Běh na lyžich. Praha: Karolinum.

Janda, V., Poláková, Z., Véle, F. (1996). Funkce hybného systému. Praha: Státní zdravotnické nakladatelství.

Kapandji, A. I. (1987). The physiology of the Joints. Volume Two (Lower Limb). Edinburg: Churchill Livingstone.

Kračmar, B. (2001). Exploitation of reflexive locomotion theory by qualitative analysis of sports activity. Acta Universitatis Carolinae Kinantropologica, 37, 38-46.

Kračmar, B. (2002). Kineziologická analýza sportovního pohybu. Praha: Triton.

Romer, A. S. (1966). Vertebrate Paleontology. Chicago, London: The University of Chicago Press. P. 248-252.

Schmalhausen, I. I. (1968). The Origin of Terrestrial Vertebrates. New York: Academic Press. P. 187-195.
Shubin, N., Alberch, P. (1986). A morphogenetic approach to the origin and basic organisation of the tetrapod limb. Evolutionary Biology, 20, 319-387.

Vacková, P. (2004). Fylogenetické souvislosti sportovní lokomoce. Praha: Thesis.

Vančata, V. (1996). Ontogeny of Primate Locomotion and the Origin of Hominid Bipedality. Folia Primatologica, $67,213-214$.

Vařeka, I. (2004). Dynamický model „tř́íbodové“ opory nohy. Rehabilitácia, 41, 132-136.

Véle, F. (2006). Kineziologie. Praha: Triton. P. 190193.

Vojta, V., Peters, A. (1995). Vojtův princip. Praha: Grada Publishing.

Young, J. Z. (1981). The Life of Vertebrates. Oxford: Clarendon Press. P. 328-331. 


\title{
SLYDIMO LENKTYNINE்MIS SLIDE்MIS IR RIEDSLIDE்MIS KINEZIOLOGIJOS YPATYBIŲ ANALIZE்
}

\author{
Jiří Suchý, Bronislav Kračmar \\ Prahos Karlo universitetas, Praha, Čekija
}

\begin{abstract}
SANTRAUKA
Žmogaus judejimo ontogenezès kulminacinis taškas yra vaikščiojimas ant dviejų kojų be atramos. Galima manyti, kad judejimas sportuojant atitinka vaikščiojimo modeli. Šio tyrimo metu buvo stebima judesiu koordinacija analizuojant šešių svarbiausių raumenu grupių darbą tiriamiesiems slystant lenktyninėmis slidèmis su lazdomis (laisvuoju čiuožimo stiliumi), o rezultatai palyginti su koordinacijos rodikliais riedant riedslidėmis su lazdomis ant asfalto. Tyrimas atliktas sportininkams slystant į nedidelę ikkalnę. Kiekvieno asmens judejjimas buvo analizuojamas naudojantis elektromiografija (EMG) ir skaitmeniniais vaizdo įrašais, užfiksuotais natūralioje aplinkoje. Gauti duomenys įvertinti apskaičiuojant plotą po kiekvieno stebimo raumens EMG kreive. Tokiu būdu gauti patikimumo rodikliai rodo tiriamojo raumens aktyvumą ir darbą. Maksimalių reikšmių išsidėstymas per vieno žingsnio ciklą leido įvertinti judesių koordinaciją.

Gauti matavimai patvirtino kojų raumenų trejopo ịtempimo ir dubens stabilumo priekinèje plokštumoje vienatraminès padèties reiškinį. Šị stabilumą garantuoja išmatuotas musculus gluteus medius, rodantis kitoki maksimalių reikšmių išsidèstymą EMG kreiveje, lyginant visus slidininkų judesius ant asfalto ir ant sniego. Šio raumens aktyvumo didžiausi rodikliai buvo nustatyti už musculus latissimus dorsi aktyvumo kulminaciniu taškų, todèl galima manyti, kad šis raumuo lemia judejjimo kokybę ir atlieka stabilizavimo funkciją. Šitaip kaitaliodamiesi abu raumenys garantuoja stabilumą.

Šio tyrimo rezultatai parodè, kad judesių slystant slidėmis ir riedslidèmis su lazdomis kineziologijos ypatybės yra panašios. Vadinasi, riedslides galima reguliariai naudoti kaip specifinę slidinèjimo pratybu priemonę.
\end{abstract}

Raktažodžiai: žmogaus judejjimas, elektromiografija, slydimas lenktyninėmis slidėmis ir riedslidèmis.

Gauta 2008 m. kovo 6 d.

Received on March 6, 2008

Priimta $2008 \mathrm{~m}$. birželio $18 \mathrm{~d}$.

Accepted on June 18, 2008

\author{
Jiř́ Suchý \\ Charles University in Prague \\ (Prahos Karlo universitetas) \\ José Martího 31, 16252 Prague 8211, Veleslavín \\ Czech Republic (Čekijos Respublika) \\ Tel +420608 117536 \\ E-mail email@jirisuchy.cz
}

